\title{
CELLULASE AND XYLANASE PRODUCTION BY ISOLATED AMAZON BACILLUS STRAINS USING SOYBEAN INDUSTRIAL RESIDUE BASED SOLID-STATE CULTIVATION
}

\author{
Júlio X. Heck; Plinho F. Hertz; Marco A.Z. Ayub*
}

BiotecLab, Instituto de Ciência e Tecnologia de Alimentos, Universidade Federal do Rio Grande do Sul, Porto Alegre, RS, Brasil

Submitted: February 01, 2002; Returned to authors for corrections: April 18, 2002; Approved: August 30, 2002

\begin{abstract}
In Brazil, a large amount of a fibrous residue is generated as result of soybean (Glycine max) protein production. This material, which is rich in hemicellulose and cellulose, can be used in solid state cultivations for the production of valuable metabolites and enzymes. In this work, we studied the bioconversion of this residue by bacteria strains isolated from water and soil collected in the Amazon region. Five strains among 87 isolated bacteria selected for their ability to produce either celullases or xylanases were cultivated on the aforementioned residue. From strain BL62, identified as Bacillus subtilis, it was obtained a preparation showing the highest specific cellulase activity, $1.08 \mathrm{UI} / \mathrm{mg}$ protein within 24 hours of growth. Concerning xylanase, the isolate BL53, also identified as Bacillus subtilis, showed the highest specific activity for this enzyme, $5.19 \mathrm{UI} / \mathrm{mg}$ protein within 72 hours of cultivation. It has also been observed the production of proteases that were associated with the loss of cellulase and xylanase activities. These results indicated that the selected microorganisms, and the cultivation process, have great biotechnological potential.
\end{abstract}

Key words: Solid-State cultivation, cellulase, xylanase, soybean residue, Amazon biodiversity

\section{INTRODUCTION}

A great deal of research on the enzymatic degradation of cellulose and hemicellulose has been developed in the last 30 years (18). Organic wastes from renewable forest and agricultural residues are rich sources of cellulose, hemicellulose and lignin, in an average ratio of 4:3:3 (3) although the exact percentage of these components varies from source to source (24).

Cellulose, the largest renewable carbon source available (approximately 150 billion tons of organic material is photosynthesized annually), is frequently found in close association with other compounds, such as hemicellulose, lignin and other polysaccharides, which makes its bioconversion more difficult (17). Cellulose is an unbranched glucose polymer, composed of anhydro-D-glucose units linked by $1,4-\beta-D-$ glucoside bonds, which can be hydrolyzed by cellulolytic enzymes (18) produced by both bacteria and fungi. Cellulolytic bacteria include aerobic species such as Pseudomonas and
Actynomicetes, facultative anaerobes such as Bacillus and Cellulomonas, and strict anaerobes such as Clostridium. The commercial possibility of using cellulase preparations to produce glucose, alcohol and protein from cellulose is under intensive study (11).

Hemicellulose is the second most abundant plant fraction available in nature. It is a storage polymer in seeds being also a structural component of cell walls in woody plants. Waste residues contain up to $40 \%$ hemicelluloses formed by pentose sugars (12). The monomers of various hemicelluloses are useful in the production of different antibiotics, alcohols, animal feed, chemical specialities and fuels (26). Xylan is the most abundant of the hemicelluloses. It has a linear backbone comprised of $\beta$ - 1,4 -linked D-xylopyranose residues, which, depending on the origin, may present ramifications containing mainly acetyl, arabinosyl and gluconosyl residues (9). There is a great interest in the enzymatic hydrolysis of xylan due to possible applications in feedstock, fuel and chemical production, and paper manufacturing (6).

\footnotetext{
* Corresponding author. Mailing address: Instituto de Ciências e Tecnologia de Alimentos, Laboratório de Biotecnologia, Av. Bento Gonçalves, 9500, Caixa Postal 15090, Campus do Vale. 91501-970, Porto Alegre, RS, Brasil. Telefax: (+5551) 3316-6685. E-mail: mazayub@ufrgs.br
} 
Solid state cultivation (SSC) can be defined as the microbial cultivation process in the absence or near absence of free water in the substrate (15). However, there must be enough moisture present to support cell growth (16). As bacteria, yeasts and filamentous fungi can grow on solid substrates SSC has been used in bioprocesses (19). Besides, SSC has some advantages over submerged cultivation, including conditions that are similar to those of the natural habitat of the microorganisms, lower costs and improved enzyme stability (9). SSC has been used for the production of cellulolytic and xylanolytic enzymes. At the end of the cultivation, enzymes can be extracted from the substrate by simply percolating the bioreactor with appropriated buffers which is an easy, economical operation (17).

Brazil is the second largest soybean (Glycine max) world producer. The industrial processing of this seed, to obtain isolated protein, generates a large amount of fibrous residues. This material is mainly composed of $23 \%$ hemicellulose, $16 \%$ cellulose, and $28 \%$ insoluble protein (dry basis). It has been estimated by our studies that approximately 10,000 tn/year of this rich by-product are currently being produced, which is partially used for animal feeding complement or is simply disposed off in the environment (10).

The aims of this research are to study the bioconversion of soybean fibrous residue into value-added industrial products, such as enzymes, using SSC, and the selection of new bacteria strains from the Amazon region biodiversity for bioprocess applications.

\section{MATERIALS AND METHODS}

\section{Industrial fibrous soybean residue}

Industrial fibrous soybean residue (IFSR), a by-product from soybean processing for protein isolation, was used as the cultivation substrate. IFSR composition was determined according to the method of Van Soest and Robertson for cellulose and hemicellulose (27). Sucrose and protein contents were determined by Fehling and Kjeldahl methods respectively (1).

\section{Microorganisms}

The five strains of Bacillus used in this study were isolated from samples of soil and water of the Amazon region, and kindly provided by Prof. Spartaco Astolfi-Filho. They were selected according to their cellulolytic and xylanolitic activities. Strains were maintained on agar medium containing $0.1 \%$ tragacanth gum and $0.1 \%$ carboxymethyl cellulose. Bacteria were identified according to standard biochemical methods (22).

\section{Medium}

A basic liquid mineral medium showing the following composition $\left(\mathrm{g} \mathrm{l}^{-1}\right)$ : $0.2 \mathrm{MgSO}_{4}, 1.0 \mathrm{KH}_{2} \mathrm{PO}_{4}, 1.0 \mathrm{~K}_{2} \mathrm{HPO}_{4}, 1.0$
$\mathrm{NH}_{4} \mathrm{NO}_{3}, 0.02 \mathrm{CaCl}_{2}$, and $0.05 \mathrm{FeCl}_{2}$ was used for both inoculum preparation and SSC. SSC inoculum was prepared in $200 \mathrm{~mL}$ Erlenmeyer flasks containing $1.2 \mathrm{~g}$ of IFSR and $40 \mathrm{~mL}$ of basic liquid mineral medium. Flasks were inoculated with a single colony from an agar plate culture and incubated for $18-20 \mathrm{~h}$ at $37^{\circ} \mathrm{C}$ under agitation $(125 \mathrm{rpm})$.

\section{Bioreactor and Cultivation Conditions}

Bioreactor experiments were carried out using a $500 \mathrm{~mL}$ cylindrical bioreactor ( $60 \mathrm{~mm}$ diameter, $170 \mathrm{~mm}$ height) designed and built in our laboratory. SSC medium was prepared with $20 \mathrm{~g}$ of dry IFSR and $50 \mathrm{~g}$ of inert support (irregular stones with approx. $5 \mathrm{~mm}$ of diameter) soaked in $120 \mathrm{~mL}$ of the liquid medium. Bioreactors filled with the substrate and the inert support, were sterilized in autoclave at $121^{\circ} \mathrm{C}$ for $15 \mathrm{~min}$. After inoculation with the entire content of an Erlenmeyer flask, cultivation proceeded at $37^{\circ} \mathrm{C}$ for 72 hours. During cultivation, humidified sterile air was supplied at a constant rate of $150 \mathrm{~mL} \mathrm{~min}^{-1}$.

\section{Enzyme Extraction}

Enzymes were extracted from the entire bioreactor content using eight volumes of water $(160 \mathrm{~mL})$ and by shaking this mixture at $150 \mathrm{rpm}$ for $30 \mathrm{~min}$. Separation of solid-liquid phase was accomplished by centrifugation at $10,600 \mathrm{~g}$ for $20 \mathrm{~min}$.

\section{Sugar content}

Total reducing sugar was measured by the dinitrosalicylic method (DNS) (4).

\section{Soluble Protein}

Soluble protein was measured by the Bradford (2) procedure, using bovine albumin as the standard.

\section{Enzymes Assays}

Cellulase activity was determined by filter paper activity (FPA), according to Mandels et al. (13). Xylanase activity was measured according to Tavares et al. (25). Cellulase and xylanase activities were expressed as micromoles of glucose equivalent liberated per minute per $\mathrm{mL}$ of enzyme solution (IU/mL). Specific activities were expressed as IU/mg protein.

\section{Proteolytic Activity Assay}

Proteolytic activity was measured by the azocasein method, according to Sarath et al. (21). One enzymatic activity unit (U) was defined as the amount of enzyme needed to produce, using a $1 \mathrm{~cm}$ cuvette, the change in one unit of absorbance under the conditions of the method. Specific activity was expressed as U/ mg protein.

\section{Statistical Analysis}

Data were analysed by ANOVA procedure (20) and comparisons between means were performed by Tukey's test. 


\section{RESULTS AND DISCUSSION}

The five bacteria strains used in this research presented the ability to produce either cellulases or xylanases, or both enzymes: BL 15 and BL 62 produced both enzymes; BL 53 and BL 69 produced xylanase, and strain BL 16 produced cellulases. BL 53 and BL 62 were identified as Bacillus subtilis, whereas BL 15, BL 16 and BL 69 were identified as Bacillus sp.

The time course of bioreactor SSC cultivations is shown in Figure 1. Strains BL 16, BL 62, and BL69 presented similar behavior towards reducing sugar liberation and consumption (Fig. 1a), as a peak of sugar concentration was observed in 24 hours of cultivation, followed by sharp decline, which indicates carbon source consumption. BL 53 strain showed an anticipated sugar liberation peak within 12 hours followed by a second peak of sugar liberation at the end of the run, probably due to de novo enzyme synthesis necessary to the hydrolysis of the substrate. BL 15 strain liberated the lowest amount of reducing sugar whose concentration remained constant up to the end of the process. Fig. $1 \mathrm{~b}$ shows the results for protein concentration. With the exception of strain BL 69, which showed very little protein variation during cultivation, all others presented an initial decrease of soluble protein, indicating consumption of available nitrogen sources. During a later stage of growth, these cultures showed increased protein liberation into the medium, indicating proteolytic activity. To confirm this hypothesis, we have tested the proteolytic activity of cultures (Fig. 2). We obtained a very high enzymatic activity for all isolates, except for BL 69 , confirming their ability to hydrolyze the residual soy protein.

Cell lyses, causing the liberation of basic amino acids and peptides into the medium, were probably responsible for a strong $\mathrm{pH}$ variation of cultures. The high values of $\mathrm{pH}$ obtained at the end of cultivations for the degradation of IFSR, shown in Figure $1 \mathrm{c}$, contrasted with results obtained for the biodegradation of other cellulosic material, as described by Cen and Xia (5), who reported a highly buffering property, with $\mathrm{pH}$ staying in between 5.5 and 7.0. Our results point to the need of $\mathrm{pH}$ control during cultivation of Bacillus over IFSR when enzymatic activities may be halted by high $\mathrm{pH}$ values.

\section{Cellulase and xylanase activities}

With the exception of strain BL69 and BL53 that showed very low cellulolytic activity, the other isolates presented considerable cellulase activity, being its maximum at 24 hours of cultivation as it is shown in Fig. 3a. Studies with cellulolytic bacteria suggest that prokaryotic cellulases may present very different action from those of fungi, with best temperature and $\mathrm{pH}$ varying among them. Therefore, comparison in terms of enzyme activity is difficult to establish (8). To overcome this limitation, and aiming at to compare the enzymes produced by the strains investigated in this work to commercial enzyme preparations (Table 1), we measured enzyme specific activity
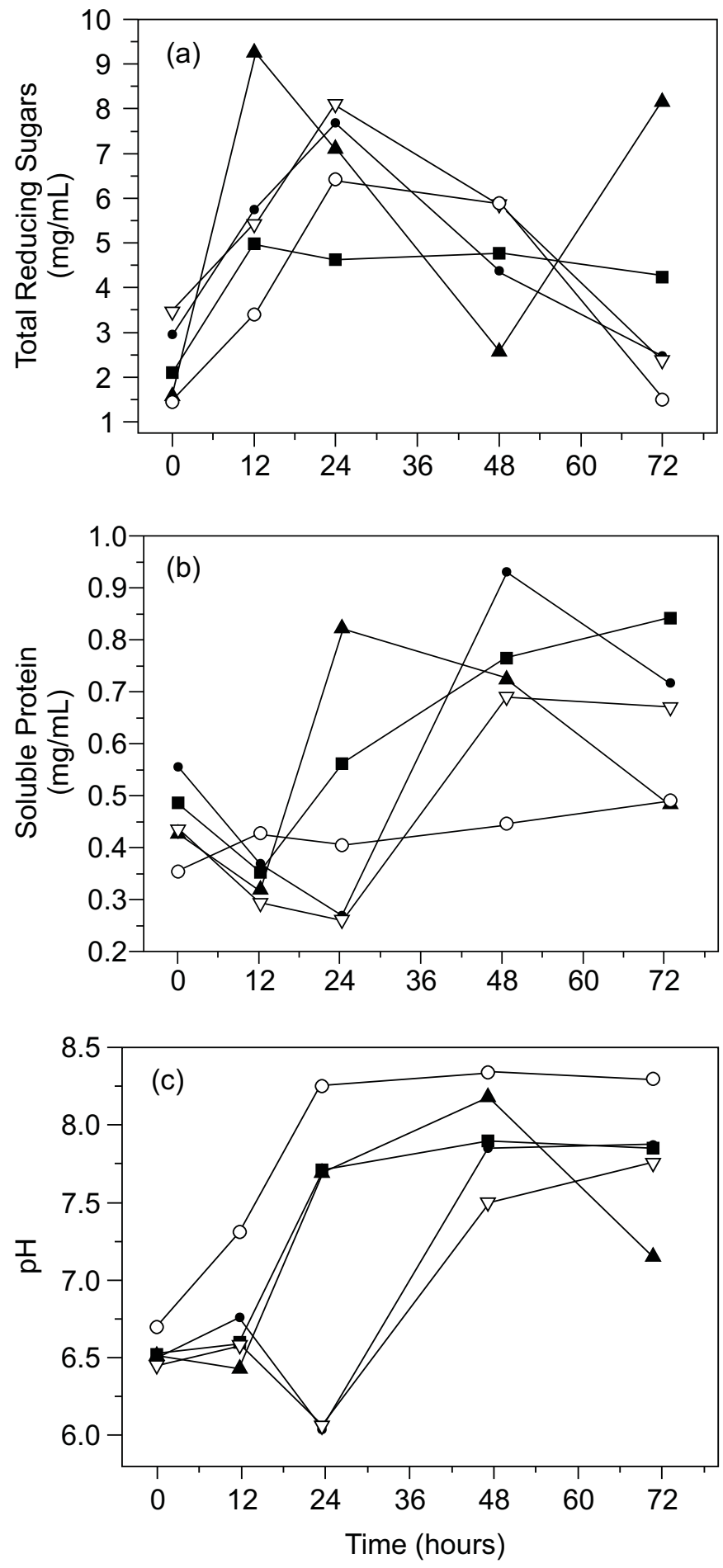

Figure 1. Cultivation time course for bioreactor $\mathrm{SSC}$ at $37^{\circ} \mathrm{C}$ and $150 \mathrm{~mL}$ air/min. (a) total reducing sugar; (b) soluble protein; (c) pH. Showing data for - - Bacillus sp. BL 15,--Bacillus sp BL16, - $\mathbf{\Delta}$ - Bacillus subtilis BL53, - $\nabla$ - Bacillus subtilis BL62, -O- Bacillus sp BL69. Results represent the average of two experiments. 


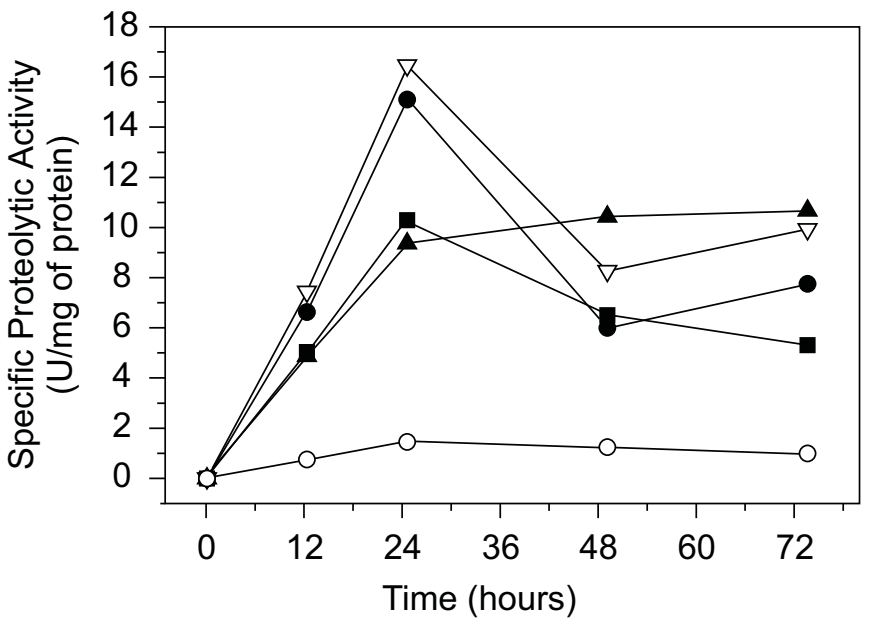

Figure 2. Specific proteolytic activity throughout SSC of IFSR at $37^{\circ} \mathrm{C}$ and $150 \mathrm{~mL}$ air/min. Showing data for - - Bacillus sp. BL 15, - - Bacillus sp BL16, - $\mathbf{\Delta}$ - Bacillus subtilis BL53, - $\nabla$ Bacillus subtilis BL62, -O- Bacillus sp BL69. Results represent the average of two experiments.

Table 1. Specific enzyme activities of commercial preparations and enzymatic extracts obtained in this work. Activity represents the higher value obtained during cultivation. Enzyme concentration of commercial preparations was equivalent to $1 \%$ (w/v) of crude powder. Means followed by different letters on column are statistically different $(\mathrm{P}<0.05)$.

\begin{tabular}{ccc}
\hline Ezyme & $\begin{array}{c}\text { Cellulase } \\
\text { Specific Activity } \\
\text { (UI/mg ptotein) }\end{array}$ & $\begin{array}{c}\text { Xylanase } \\
\text { Specific Activity } \\
\text { (UI/mg ptotein) }\end{array}$ \\
\hline Prozyn* $^{*}$. & $0.87^{\mathrm{A}}$ & ND \\
ACX6000-P** $^{*}$ & $\mathrm{ND}$ & $1.37^{\mathrm{A}}$ \\
HBC-5** & $\mathrm{ND}$ & $1.03^{\mathrm{A}, \mathrm{C}}$ \\
Bacillus sp. BL15 & $0.72^{\mathrm{A}}$ & $1.75^{\mathrm{B}}$ \\
Bacillus sp. BL16 & $0.89^{\mathrm{A}}$ & $0.88^{\mathrm{C}}$ \\
Bacillus subtilis BL53 & $0.23^{\mathrm{B}}$ & $5.19^{\mathrm{D}}$ \\
Bacillus subtilis BL62 & $1.08^{\mathrm{C}}$ & $4.06^{\mathrm{E}}$ \\
Bacillus sp. BL69 & $0.06^{\mathrm{B}}$ & $1.28^{\mathrm{A}}$ \\
\hline
\end{tabular}

* Commercial Cellulase - Novo Nordisk; ** Commercial hemicellulase - Trigotec Ltda.; ND - Not determinated.

for both cases. Results shown that isolates BL15, BL16, and BL62 have similar cellulase specific activity as shown by Prozyn $^{\mathrm{TM}}$, a widely used industrial enzyme. Concerning the production of xylanase, all strains presented some activity but profiles varied among them as shown in Figure $3 \mathrm{~b}$. The isolate BL53 presented the highest xylanase activity within 72 hours of cultivation (5.19 UI/mg protein). BL62, which presented the
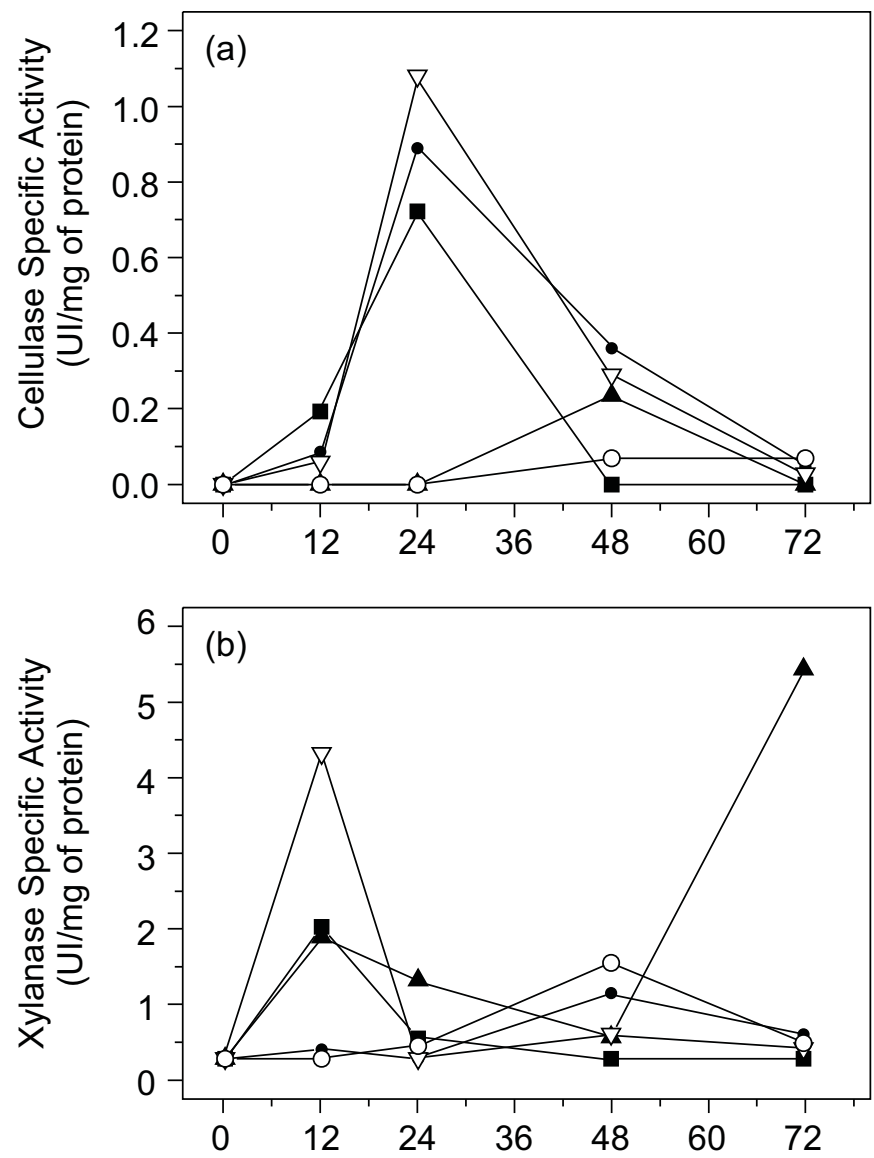

Figure 3. Specific enzyme activities of (a) Cellulase, and (b) Xylanase throughout SSC of IFSR at $37^{\circ} \mathrm{C}$ and $150 \mathrm{~mL}$ air $/ \mathrm{min}$. Showing data for--Bacillus sp. BL 15,-- Bacillus sp. BL16, - $\mathbf{\Delta - B a c i l l u s ~ s u b t i l i s ~ B L 5 3 , - \nabla - B a c i l l u s ~ s u b t i l i s ~ B L 6 2 , - O - ~}$ Bacillus sp BL69. Results represent the average of two experiments.

highest cellulase activity, also showed a reasonable xylanase production (4.07 UI/mg protein) but, in contrast with BL53, its peak was at the initial phase of cultivation, 12 hours. This difference might be related to the ability of strains in initially using carbon sources other than cellulose and hemicellulose that are present in IFSR. The complete analysis of the SSC substrate residue showed $17 \%$ (dw) content on sugars such as raffinose, stachyose, and arabinose, which may be used or not, depending on the metabolic capabilities of strains. Protein preparations obtained from strains BL53 and BL62 compared favorably to commercial xylanases, as shown in Table 1, with activities being four to five times higher. Silva et al. (23) described SSC production of xylanase by Aspergillus fumigatus Fresenius growing for seven days. The maximum productivity obtained in their work was of $6.27 \mathrm{UI} / \mathrm{mg}$ protein, similar to that for BL53 within 72 hours of cultivation. 
According to Moo-Young (14), the actions of cellulases and xylanases are synergetic over substrate, especially for microorganisms isolated from environments where wood and agro-residues are biodegraded. In our work, most of the strains were capable of producing both enzymes, confirming these observations. Another important aspect for industrial applications of enzymes is the need for reduced costs of production (17). Gessesse and Mamo (7) postulate that the great advantages of using SSC over submerged cultivation for enzyme production are the lower water content of enzymatic extract, easy of control, lower probability of contamination, among others. The selection of better solvents for enzyme extraction from the medium is another important point of research when selecting SSC as a biotechnological system.

\section{CONCLUSIONS}

In this work we demonstrated that some bacteria are as good producers of cellulase and xylanase as fungi are. Although is not common to use bacteria as microorganisms in SSC, in our work, the isolates from Amazonian environment proved to be excellent biological systems, showing some advantage over filamentous fungi, such as faster growth and lower probability of contaminations. Yet, recovery of extracellular enzymes is eased by the simplicity of the process. The use of agro-industrial residues as substrate for microbial growth also proved to be possible, with good perspectives for scaling up. Moreover, results obtained in this work point to the strong necessity of better understanding of the microbial diversity of Amazon region, one of the largest ecosystems on earth.

\section{ACKNOWLEDGEMENTS}

The authors whish to thank Professor Spartaco Astolfi-Filho of Universidade Federal do Amazonas, for the strains and to CNPq, CAPES and FAPERGS for their financial support.

\section{RESUMO}

\section{Produção de celulase e xilanase por cepas de Bacillus isoladas da Amazônia em culivo semi-sólido utilizando resíduo da indústria da soja}

No Brasil, uma grande quantidade de resíduos fibrosos de soja (Glycine max) são gerados no processo de produção de proteína de soja. Estes materiais, ricos em celulose e hemicelulose, podem ser usados como substratos para cultivos microbianos visando a produção de valiosos metabólitos e enzimas. Neste trabalho, estudou-se a produção de enzimas, utilizando estes resíduos, por bactérias isoladas da água e do solo da região amazônica. Cinco cepas, dentre 87 iniciais, foram selecionadas e crescidas em cultivo semi-sólido (CSS).
Preparações obtidas do isolado BL 62, identificado como Bacillus subtilis, apresentaram a maior atividade específica para celulase, 1,08 UI/ mg de proteína, em 24 horas de cultivo. No que se refere às xilanases, preparações obtidas do isolado BL 53, também identificado como Bacillus subtilis, apresentaram a maior atividade específica para esta enzima, com um valor de 5,19 UI/ mg de proteína, em 72 horas de cultivo. Também foi demonstrada a produção simultânea de proteases, o que pode ser associado à perda das atividades de celulase e xilanase durante o cultivo. Os resultados indicam que os microrganismos selecionados e o processo de cultivo empregado utilizando resíduo da soja apresentam grande potencial biotecnológico.

Palavras-chave: Cultivo semi-sólido, celulases, xilanases, resíduo de soja, biodiversidade amazônica.

\section{REFERENCES}

1. Association of Official Analytical Chemists. Official Methods of Analysis of Official Analytical Chemists. 15th ed. AOAC, Arlington. 1990.

2. Bradford M.M. A rapid and sensitive method for the quantitation of microgram quantities of protein utilizing principle of protein-dye binding. Anal. Biochem., 72: 142-146, 1978

3. Brauns, F.E.; Brauns D.A. The chemistry of lignin covering the literature for the 1949-1958. Academic Pres: San Diego, 1960, 45$47 \mathrm{p}$.

4. Chaplin, M.F. Monosaccharides. In: Chaplin M.F.; Kennedy, J.F. (eds). Carbohydrate Analysis. IRL Press, Oxford, 1986, p.1-3.

5. Cen, P.; Xia, L. Production of cellulase by solid-state fermentation. Adv. Biochem. Eng. Biotechnol., 65: 70-92, 1998.

6. Coughlan, M.P.; Hazlewood, G.P. b-1,4-D-xylan-degrading enzyme systems: biochemistry molecular biology and applications. Biotechnol. Appl. Biochem., 17: 259-289, 1997.

7. Gessesse, A.; Mamo, G. High-level xylanase production by an alkaliphilic Bacillus sp. by using solid-state fermentation. Enzyme Microb. Technol., 25: 68-72, 1999.

8. Goodfrey T; West, S. Enzimology. Macmillam Press, Whashington, 1996, p.835-845.

9. Filho, E.X.F.; Ximenes, F.A.; Fonseca, A.S.; Ximenes, E.A. XylanDegrading Enzyme Production By Solid-State Cultures of Aerobic Fungi. Rev. Microbiol., 28: 22-28, 1997.

10. Heck, J.X.; Rosa, S.P.; Soares, L.H.B.; Hertz, P.F.; Ayub, M.A.Z. 2000. Exploração da Diversidade Microbiana Isolada de Ambientes Aquáticos da Amazônia para a Produção de Enzimas de Interesse. VII Encontro Nacional de Microbiologia Ambiental, Recife, p.87.

11. Katz, M.; Reese, E.T. Procuction of glucose by enzymatic hydrolysis of cellulose. Appl. Microbiol., 16 : 419-420, 1968.

12. Magge, R.J.; Kosaric, M. Bioceonversion of hemicellulose. $A d v$ Biochem Eng Biotech., 32: 61-93, 1985.

13. Mandels, M.; Andreotti, R.; Roche, C. Measurement of saccharifyng cellulase. Biotechnol. Biogen. Symp., 6: 21-31, 1976.

14. Moo-Young M. Comprehensive Biotechnology: the principles, applications and regulation of biotechnology in industry, agriculture and medicine. Pergamon, London. 1992, 835-845p.

15. Pandey, A. Solid-state fermentation: an overview. Proc. Biochem., 27: 109-117, 1992.

16. Pandey, A.; Soccol, C. Bioconversion Of Biomass: A Case Study of Ligno-cellulosics Bioconversions in Solid State Fermentation.. Braz. Archiv. Biol. Technol., 41: 379-390, 1998.

17. Person, I.; Tjerneld, F.; Hahn-Hägerdal, B. Fungal Cellulolytic Enzyme Production. Proc. Biochem., 26: 65-74, 1990. 
18. Robson, L.M.; Chambliss, G.H. Cellulases of bacterial origin. Enzyme. Microb. Technol., 11: 612-643, 1989.

19. Rimbault, M. General and Microbiological Aspects of Solid Substrate Fermentation. J. Biotechnol., 1: 1-15, 1998.

20. SAS Institute (Cary NC). SAS user's guide: Statistical Analysis Sistem, Release 6.12 - 1998.

21. Sarath, G.; de la Motte, R.S.; Wagner, F.W. Proteases assay methods. In: Beyon, R.J.; Bond, J.S. (eds). Proteolytc enzymes: a practical approach, IRL, Oxford, 1989, p.259.

22. Sneath, P.H.A.; Mair, N.S.; Sharpe, M.E.; Holt, J.G. (eds) Bergey's. Manual of Sistematyc Bacteriology. 8 ed. Vol 2. Williams \& Wilkins, 1996.

23. Silva, C.H.C.; Puls, J.; Sousa, M.V.; Filho, E.X.F. Purification And Characterization of a Lower Molecular Wheigth Xylanase From
Solid-State Cultures of Aspergillus Fumigatus Fresenius. Rev. Microbiol., 30: 114-119, 1999.

24. Sitton, O.C.; Foutch, G.L.; Book, N.L.; Gaddy, J.L. Etanol from agricultural residues. Chem. Eng. Proc., 75: 52-57, 1979.

25. Tavares, V.B.; Gomes, E.; Silva. R Characterization of a cellulase free xylanase producing by Bacillus sp. for biobleaching of kraft pulp. Rev. Microbiol., 28: 179-182, 1997.

26. Thompson, N.S. Hemicellulose as a biomass resource. In: Solters, E.J. (ed). Wood and agricultural residues. Research on use for food, fuel and Chemical. Academic Press, San Diego, 1983, p.101119.

27. Van Soest, P.J.; Robertson, J.B. Analysis of forages and fibrous foods. A Laboratory Manual for Animal Science, 1983. [S.1.:sn.]. 